\title{
Analisis Perubahan Penggunaan Lahan Pertanian Akibat Pembangunan Jalan Tol Berbasis Citra Satelit Di Kabupaten Lampung Selatan
}

\section{Analysis of Changes In The Use of Agricultural Land Due To The Development Of Toll Roads Based on Satellite Image In Lampung Selatan District}

\author{
Lina Marlina $^{1^{*}}$, Teguh Endaryanto ${ }^{1}$, Astria Hijriani ${ }^{2}$ \\ ${ }^{1}$ Jurusan Agribisnis, Fakultas Pertanian Universitas Lampung \\ ${ }^{2}$ Jurusan Ilmu Komputer, Fakultas Matematika dan Ilmu Pengetahuan Alam, Universitas Lampung \\ *e-mail : lina.marlina@fp.unila.ac.id
}

\begin{abstract}
There are concerns that toll road construction will change livelihoods and reduce agricultural production. This study aims to map the potential agricultural land affected by toll road construction and to analyze the changes. The research was conducted from July to August 2020. The research site was in South Lampung Regency with the consideration that this area is one of the districts affected by toll road construction and is a center for food crops in Lampung Province. To see land changes carried out with a remote sensing system and then calculate the rate of land change. The rate of land conversion analyzed is in the period 2014 to 2020 in South Lampung Regency, with the assumption that in 2015, toll roads will be built and in 2020 the construction will be completed. The data source used is the 2014 and 2020 land use map of South Lampung Regency, the result of interpretation of Landsat imagery. The results showed that the toll road construction almost entirely took up agricultural potential land, both land used for plantations and food crops. Of the total land area, 72.13 percent is plantation land and 25.12 percent is land planted with food crop commodities.
\end{abstract}

Keywords: toll roads, agricultural production, conversion, satellite image

Disubmit : 30 September 2020; Diterima : 20 November 2020; Disetujui : 22 April 2021

\section{PENDAHULUAN}

Pembangunan diperlukan dalam suatu wilayah agar memberikan kesejahteraan bagi masyarakat dan juga meningkatkan perekonomian wilayah. Pembangunan ekonomi menurut Sukirno (2016) merupakan perubahan yang terjadi dengan adanya serangkaian kombinasi proses untuk menuju keadaan yang lebih baik yaitu pendapatan perkapita yang terus meningkat dalam jangka waktu yang panjang. Salah satu bentuk pembangunan yang diharapkan dapat menggerakkan perekonomian adalah pembangunan jalan tol. Menurut Khasanah et al (2017) dengan adanya pembangunan jalan tol dapat meningkatkan aksesibilitas dan kapasitas jaringan jalan dalam melayani lalu lintas serta secara tidak langsung berdampak terhadap sosial ekonomi 
masyarakat. Transportasi yang baik dan lancar akan memudahkan dalam menggerakkan ekonomi wilayah karena memberikan kemudahan dalam memasarkan produk antar wilayah.

Kabupaten Lampung Selatan merupakan daerah agraris yang sebagian besar masyarakatnya memiliki mata pencaharian sebagai petani. Data menunjukkan bahwa sektor pertanian merupakan penyumbang terbesar kontribusi perekonomian yang ada di Kabupaten Lampung Selatan, kontribusinya sebesar 31,22 persen. Berdasarkan data yang diperoleh dari Badan Pusat Statistik Provinsi Lampung (2018) bahwa Kabupaten Lampung Selatan merupakan salah satu wilayah sentra produksi padi tertinggi dengan luas lahan mencapai 45.634 Ha di Provinsi Lampung. Produksi tanaman padi yang ada di Kabupaten Lampung Selatan, yaitu padi sawah dan padi ladang. Padi sawah dan padi ladang ada hampir di semua kecamatan yang ada di Kabupaten Lampung Selatan.

Kabupaten Lampung selatan merupakan wilayah yang terkena dampak langsung pembangunan jalan ton. Kabupaten ini memiliki kepentingan untuk menggerakkan perekonomian di sepanjang jalan tol yang melintasi 11 Kecamatan dan 61 Desa. Namun, Sebagai basis sektor pertanian, khususnya tanaman pangan, dengan adanya pembangunan jalan tol dikhawatirkan merubah mata pencaharian dari sebelumnya bertani serta berakibat terhadap penurunan produksi pertanian yang berdampak terhadap rendahnya ketahanan pangan wilayah Provinsi Lampung. Destianto \& Pigawati (2014) menyatakan bahwa terjadinya perubahan lahan pertanian tersebut menjadi ancaman yang serius terhadap keberlanjutan kemandirian, ketahanan, dan kedaulatan pangan di suatu wilayah. Perubahan lahan pertanian terjadi karena peningkatan jumlah penduduk yang mempengaruhi penambahan permintaan lahan permukiman setiap tahun. Demikian pula hasil penelitian Khasanah et al (2017) bahwa pembangunan jalan tol menyebabkan hasil panen menurun karena lahan yang digunakan untuk bertani semakin berkurang, jalan desa menjadi rusak.

Seperti diketahui bahwa pembangunan jalan tol mengambil alih tidak hanya tempat tinggal penduduk namun juga lahan produktif miliki petani. Padahal lahan bagi petani memiliki nilai tinggi bukan hanya sebagai tempat untuk budidaya tanaman namun juga memiliki nilai sosial. Penelitian Putra (2014) menunjukkan bahwa bagi petani fungsi lahan tidak hanya sekedar untuk bercocok tanam secara subsisten saja. Namun lebih jauh lagi untuk membentuk struktur sosial petani, kebudayaan petani dan sebagai media transformasi energi antara sistem sosial petani dengan ekosistem pertaniannya. Berdasarkan penelitian Destianto \& Pigawati (2014) akibat dari adanya alih fungsi lahan karena beberapa hal salah satunya karena pengalih fungsian lahan pertanian menyebabkan terjadinya penurunan produksi pangan sebesar $9,51 \%$. Penurunan lahan akan berdampak terhadap ketersediaan pangan untuk memenuhi kebutuhan konsumsi masyarakat (Norfahmi et al., 2019). Pembangunan jalan tol di Kabupaten Lampung Selatan juga telah merubah Rencana tata Ruang dan Wilayah dimana beberapa kecamatan yang merupakan kawasan sentra produksi pertanian seperti Palas dan Sragi dialihfungsikan sebagai jalan tol (Harian Pilar, 2017). Penelitian BPP Kabupaten Lampung Selatan dan LPPM Unila (2017) menunjukkan bahwa lebih dari $30 \%$ pembangunan jalan tol mengambil lahan pertanian. Hal ini juga tentunya secara langsung berdampak terhadap penurunan hasil pertanian di Kabupaten Lampung Selatan karena lahan yang sudah terkonversi tidak akan mungkin lagi dikembalikan fungsinya seperti semula. Selain itu akan secara tidak langsung efek multipliernya berdampak terhadap tingkat pendapatan dan kesejahteraan masyarakat dalam jangka panjang.

Perubahan luasan lahan terkait dengan perubahan penggunaan dan tutupan lahan merupakan bidang kajian informasi spasial yang dapat menggunakan teknologi penginderaan jauh. Penggunaan lahan terkait dengan aktifitas manusia dan variasi perubahannya dalam periode waktu tertentu. Aplikasi data dari penginderaan jauh memungkinkan untuk melakukan studi atas perubahan lahan luas dalam waktu yang singkat, biaya yang lebih rendah dan akurasi (Pandian et al 2014). Pada penelitian ini akan dilihat perubahan konversi lahan melalui data penginderaan jauh untuk menganalisa luasan area yang merupakan peruntukan awal kondisi lahan pertanian sebelum dan sesudah pembangunan jalan tol. Penelitian diharapkan dapat memberikan informasi yang dibutuhkan untuk pengambilan kebijakan terkait dengan pembangunan Hal 12 Volume 5, Nomor 1,Tahun 2021 
pertanian di Kabupaten Lampung Selatan dan juga Provinsi Lampung. Adapun penelitian ini bertujuan memetakan lahan pertanian potensial yang terkena pembangunan jalan tol dan dan analisa perubahannya.

\section{METODE PENELITIAN}

Penelitian dilaksanakan pada Bulan Juli hingga Agustus 2020. Tempat penelitian di Kabupaten Lampung Selatan. Lokasi dipilih secara purposive dengan pertimbangan wilayah ini merupakan salah satu kabupaten yang terkena pembangunan jalan tol. Lokasi ini juga merupakan sentra tanaman pangan di Provinsi Lampung.

Jenis data yang digunakan dalam penelitian ini adalah data skunder. Data diperoleh dari berbagai sumber kepustakaan dan referensi, penelitian terdahulu serta dari instansi terkait diantaranya Badan Pusat Statistik (BPS), Bakorsultanal, dan Pemerintah Kabupaten Lampung Selatan. Peta dasar diperoleh dari Citra Satelit menggunakan google earth dan dari BAPPEDA Observasi di lapangan juga dilakukan terutama untuk menunjang pembuatan peta penggunaan lahan sebelum dan sesudah pembangunan jalan tol.

\section{Pemetaan Lahan Pertanian Potensial Yang Terkena Pembangunan Jalan Tol dan Analisa Perubahannya}

Perubahan lahan dilakukan dengan system penginderaan jauh dan selanjutnya menghitung laju perubahan lahan. Laju konversi lahan yang dianalisis yaitu dalam kurun waktu tahun 2014 sampai 2020 di Kabupaten Lampung Selatan dengan asumsi tahun 2015 mulai dibangun jalan tol dan pada tahun 2020 pembangunan sudah selesai. Sumber data yang digunakan adalah peta penggunaan lahan Kabupaten Lampung Selatan tahun 2014 dan 2020 hasil interpretasi citra landsat. Ada beberapa tahapan dalam pemetahaan lahan yaitu:

a. Pengunduhan citra landsat tahun 2014 dan 2020 dari website google earth

b. Pengunduhan peta jalan tol, peta pola ruang, peta administrasi Bappeda Kabupaten Provinsi Lampung

c. Melakukan koreksi geometri terhadap citra landsat tahun 2014 dan 2020

d. Melakukan digitasi wilayah sepanjang jalan tol serta kiri kanan jalan tol atau wilayah rumaja untuk peta tahun 2020

e. Melakukan overlay dan digitasi untuk area tanaman pangan, perkebunan, dan pemukiman pada peta jalan tol yang sudah dilakukan digitasi untuk peta tahun 2014

f. Menentukan komposit warna pada masing area yang telah dilakukan digitasi untuk mengidentifikasi perubahan lahan

g. Menghitung nilai hasil digitasi luasan jalan tol pada tahun 2020 dan luasan area pada tahun 2014

\section{HASIL DAN PEMBAHASAN \\ Gambaran Umum Wilayah Penelitian}

Kabupaten Lampung Selatan merupakan salah satu kabupaten yang memiliki laju pertumbuhan Produk Domestik Rogional Bruto (PDRB) cukup tinggi yaitu sebesar 5,14 persen terhadap Provinsi Lampung. Tingkat PDRB tersebut dipengaruhi oleh beberapa lapangan usaha atau industri yang ada. Adapun lapangan usaha di Kabupaten Lampung Selatan dalam menyumbang PDRB tahun 2019. Lapangan usaha pertanian, kehutanan, dan perikanan memiliki konstribusi yang tinggi terhadap PDRB di Kabupaten Lampung Selatan. PDRB Kabupaten Lampung Selatan berdasarkan dasar harga berlaku sebesar 28,80 persen yang berarti pada tahun 2019 pertanian memiliki konstribusi tertinggi terhadap perekonomian Kabupaten Lampung Selatan. Berbeda halnya dengan PDRB Kabupaten Lampung Selatan atas dasar harga konstan 
sebesar 2,53 persen yang berarti laju pertumbuhan ekonomi di bidang pertanian berdasarkan harga pada satu tahun tertentu yang dijadikan sebagai tahun dasar memiliki kontribusi yang paling kecil dibandingkan dengan lapangan usaha lainnya. Hal tersebut berarti lapangan usaha pertanian meningkat sebesar 2,53 persen dibandingkan dengan tahun sebelumnya, sedangkan lapangan usaha lainnya mengalami peningkatan di atas angka peningkatan laju pertumbuhan lapangan usaha pertanian.

Selain pertanian, lapangan usaha pengolahan industri juga memiliki peranan penting terhadap PDRB Kabupaten Lampung Selatan karena industri tersebut juga menyumbang angka yang tinggi terhadap PDRB. Pengolahan industri di Indonesia sebagian besar memiliki bahan baku yang berasal dari pertanian, mulai dari industri kertas yang berasal dari bahan baku kayu, industri pakaian yang berasal dari bahan baku kapas, ataupun indutri-industri pengolahan makanan yang bahan utamanya adalah hasil pertanian. Hal tersebut menandakan bahwa tingginya kontribusi industri pengolahan di Kabupaten Lampung Selatan tidak menutup kemungkinan dipengaruhi oleh tingginya lapangan usaha pertanian. Pertumbuhan ekonomi menunjukan jangkauan aktivitas perekonomian yang menghasilkan ekskalasi pendapatan masyarakat dalam periode tertentu. Pendapatan masyarakat sebagai pemilik faktor produksi diharapkan turut meningkat selaras dengan mening \% a pertumbuhan ekonomi. Pertumbuhan ekonomi Kabupaten Lampung Selatan dapat dilihat pada Gambar 1.

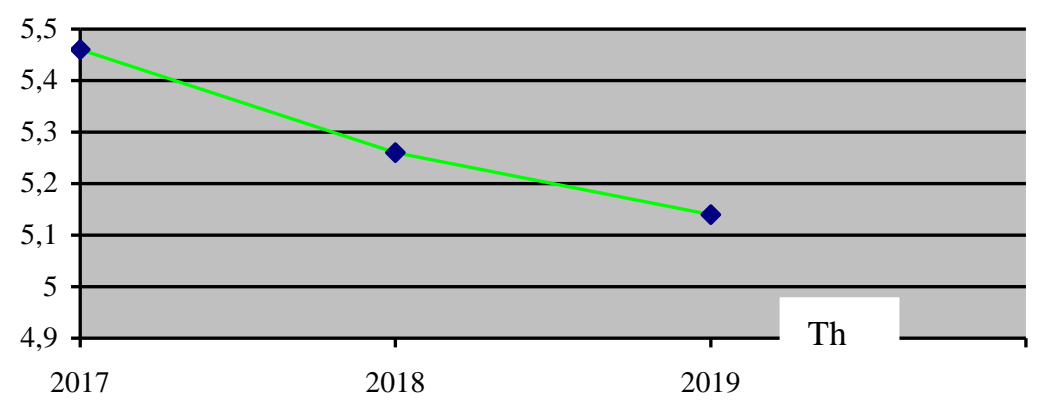

Sumber : Badan Pusat Statistik Provinsi Lampung (2018)

Gambar 1. Laju pertumbuhan ekonomi di Kabupaten Lampung Selatan tahun 2017-2019

\section{Wilayah Terkena Dampak Jalan Tol}

Wilayah Kabupaten Lampung Selatan merupakan wilayah yang terkena pembangunan jalan tol sumatera di Provinsi Lampung yang cukup luas. Kabupaten Lampung Selatan terdiri dari 17 kecamatan dengan banyak desa di dalamnya. Pembangunan jalan tol di Provinsi Lampung dimulai sejak tahun 2015 hingga 2019. Pembangunan infrastruktur dalam hal ini jalan tol menyebabkan adanya perubahan pola tata ruang. Jika sebelumnya merupakan lahan produktif seperti tanaman perkebunan dan pangan beralih fungsi menjadi jalur tol. Data dari peta administratif Kabupaten Lampung Selatan terdapat beberapa wilayah yang terkena daerah tol diantaranya Kecamatan Bakauheni, Penengahan, Kalianda, Sidomulyo, Candipuro, Ketibung, Merbau Mataram, Way Sulan, Tanjung Bintang, Jati Agung, dan Natar.

Pembangunan jalan tol pada umumnya melewati areal kebun, tanaman pangan dan juga pemukiman. Berdasarkan hasil observasi di lapangan sepanjang jalan tol dari natar hingga bakauheni ada beberapa titik wilayah kebun dengan komoditi sawit, karet, dan kelapa dalam. Untuk areal tanaman pangan, komoditi yang beralih fungsi adalah padi, jagung, dan ubi kayu. Data pada peta ruang administrasi dapat terlihat jalan tol di Kabupaten Lampung Selatan melewati kawasan pertania 


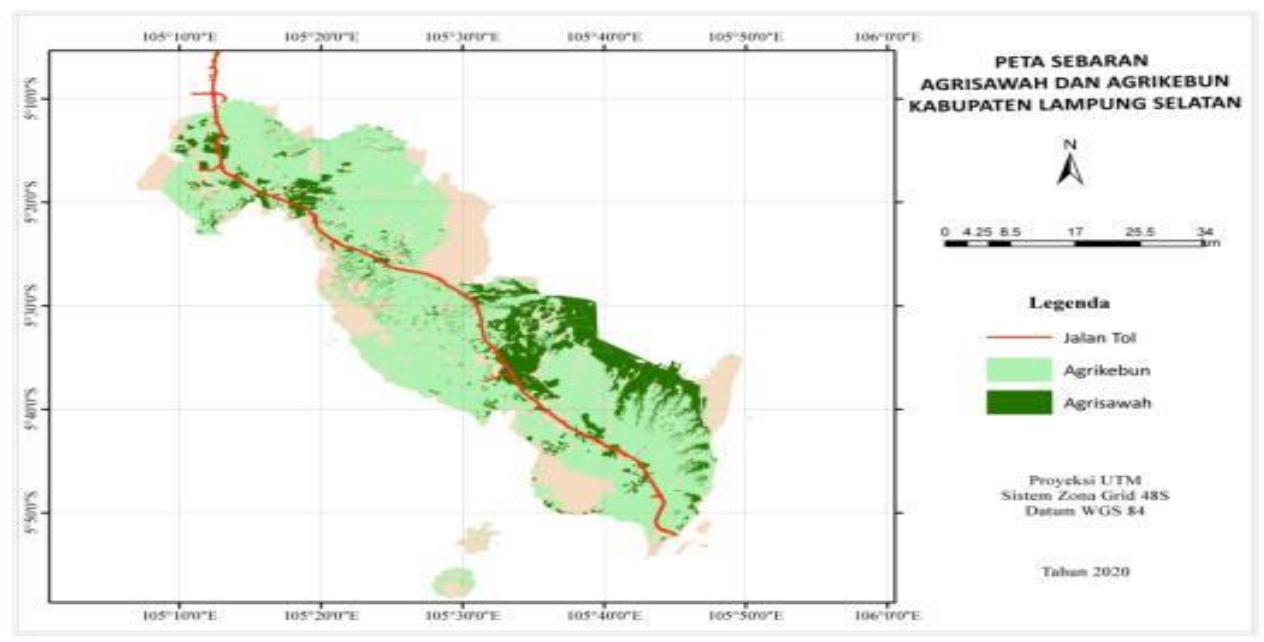

\section{Pemetaan Lahan Pertanian Potensial Yang Terkena Pembangunan Jalan Tol dan Analisa Perubahannya}

Analisis yang dilakukan dengan membandingkan kondisi wilayah sebelum dan sesudah pembangunan jalan tol di Kabupaten Lampung Selatan. Peta diambil dalam dua waktu tahun 2014 dan 2020 dengan mengunduh peta dari google earth. Ruas jalan yang diambil dari gerbang tol kalianda hingga tol bakau, pengambilan daerah ini dengan mempertimbangkan jalan tol yang dibangun melewati beberapa kecamatan dengan lahan dan produksi tanaman pangan terbesar,

Peta perubahan lahan pertanian dari sebelum pembangunan jalan tol dan sesudahnya dengan melakukan digitasi pada tahun dasar yaitu tahun 2020. Peta yang menggunakan citra satelit dengan google earth. Pada awalnya peta yang digunakan untuk analisis akan diambil dari Sentinel dan diolah menggunakan software SIG, namun data yang dibutuhkan tidak dapat diperoleh karena tertutup awan sehingga image satelit diperoleh dari google earth. Google earth memiliki kelebihan diantaranya data lebih akurat, tidak dilakukan proses klasifikasi untuk identifikasi pixel dengan label tutupan lahan, dan marjin eror yang kecil (akibat adanya digitasi). Setelah digitasi peta tahun 2020 selesai dilakukan selanjutnya menambahkan warna transparan pada polygon sehingga membantu dalam digitasi berikutnya. Proses digitasi dilakukan sepanjang jalan tol dari gerbang tol kalianda hingga pelabuhan bakauheni. Wilayah yang dilakukan digitasi selain jalan tol juga daerah daerah kiri dan kanan jalan atau juga disebut Ruang Manfaat Jalan (RUMAJA).

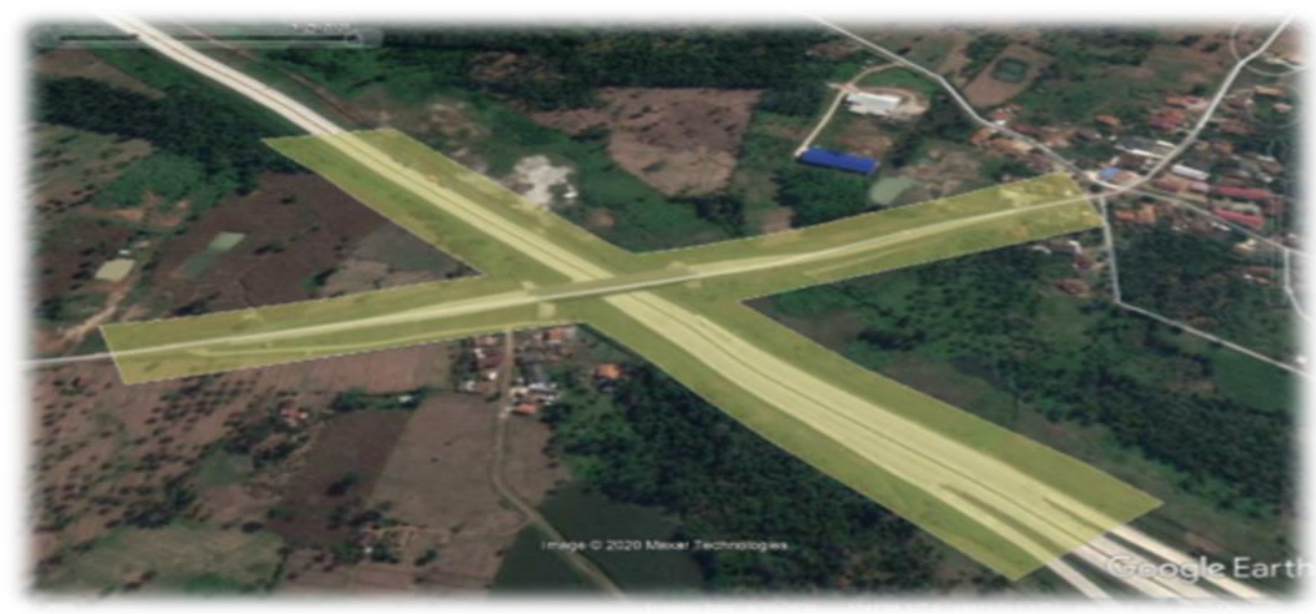

Gambar 2. Proses digitasi daerah sepanjang jalan tol tahun 2020 
Setelah dilakukan digitasi pada wilayah Kabupaten Lampung Selatan pada tahun 2020 selanjutnya melakukan digitasi peta pada daerah yang sama pada tahun 2014. Tahun 2014 dipilih karena image satelit cukup jelas sehingga dapat diperkirakan gambaran objek yang terlihat. Area dibagi dalam kategori yaitu lahan perkebunan, tanaman pangan, dan pemukiman. Saat objek terlihat dalam peta merupakan tanaman perkebunan dengan kontur berbentuk pohon maka dibuat polygon dan ditandai dengan warna hijau tua. Kemudian digitasi dataran rendah diasumsikan merupakan area tanaman pangan (padi, jagung, ubi kayu, dan lainnya) diberi warna hijau muda. Sedangkan polygon pemukiman diberi warna merah.

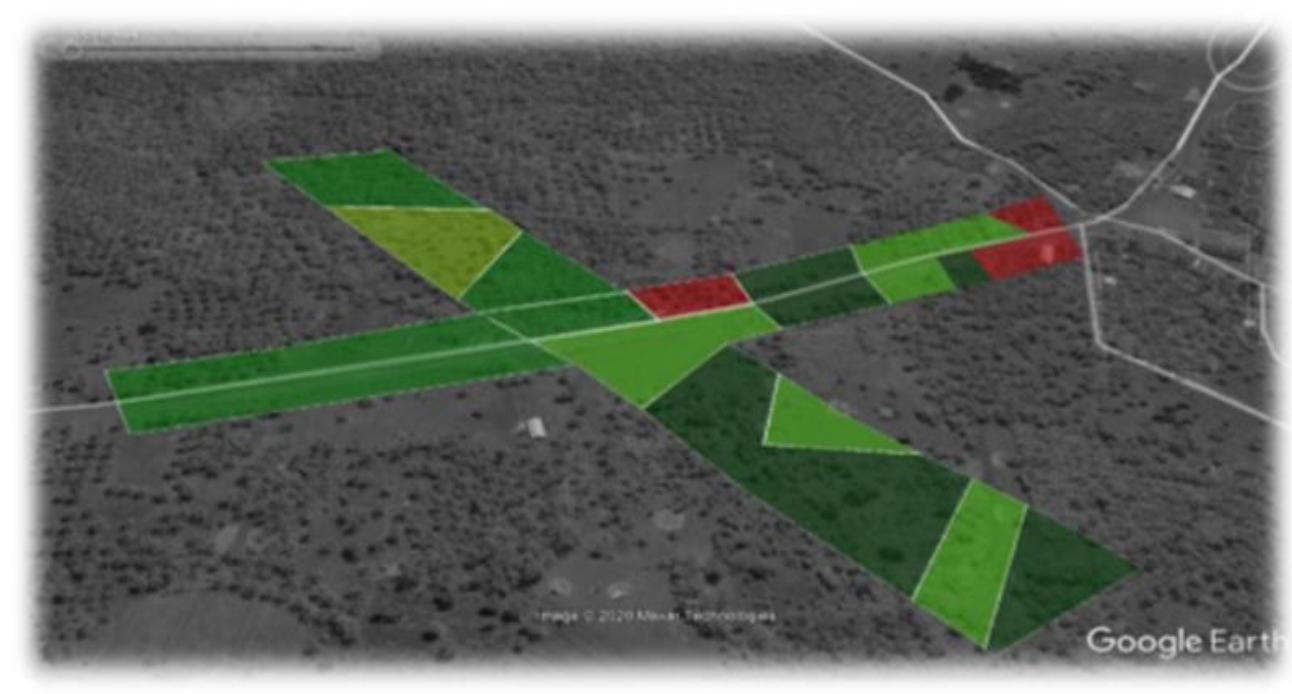

Gambar 3. Proses digitasi daerah sepanjang jalan tol tahun 2014

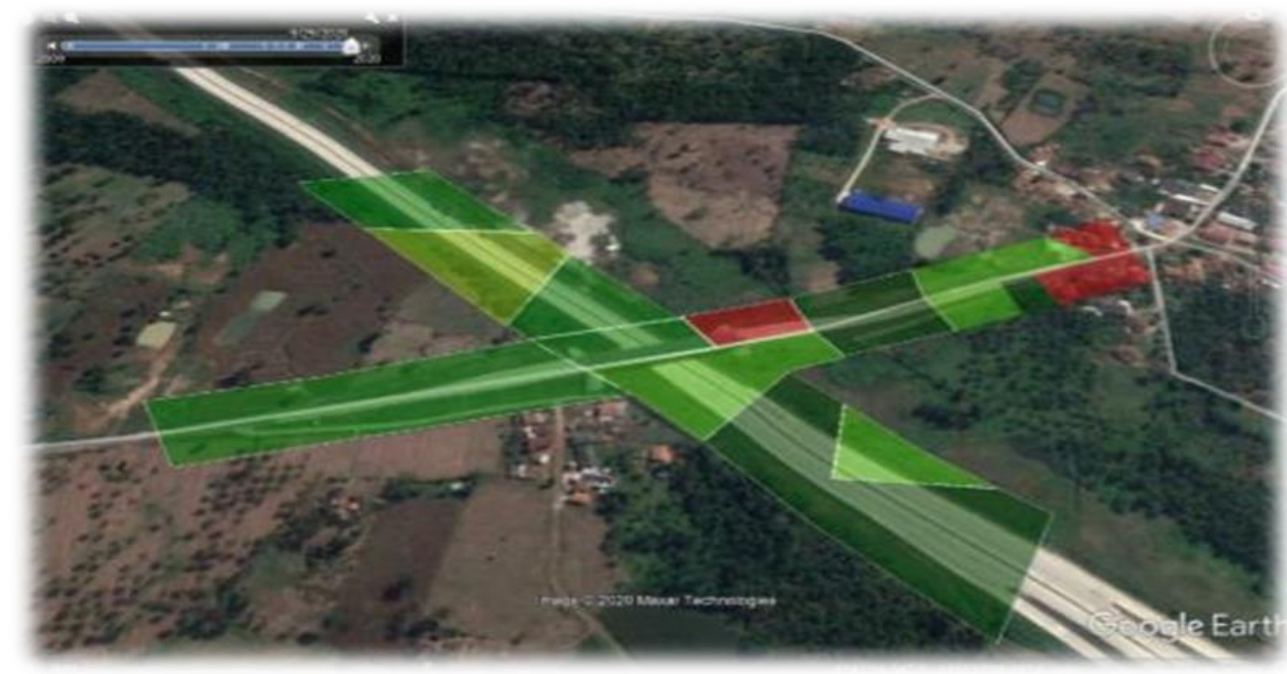

Gambar 4. Overlay kondisi sebelum dan sesudah jalan tol

Setelah proses digitasi dilakukan dilakukan overlay untuk dua waktu sehingga dapat diperoleh informasi area lahan pertanian yang hilang sebagai akibat dari pembangunan jalan tol. Poligon-poligon yang ada dihitung luasnya untuk mendapatkan luas area perkebunan, tanaman pangan, dan pemukiman. Secara lengkap dapat dilihat pada Tabel 1. 
Tabel 1. Luas tutupan lahan yang terkena dampak pembangunan Jalan Tol Kalianda hingga Tol Pelabuhan Bakauheni

\begin{tabular}{lrrrr}
\hline \multicolumn{1}{c}{ Areal } & \multicolumn{1}{c}{$\begin{array}{c}\text { Kalianda }- \\
\text { Bakau Selatan }\end{array}$} & $\begin{array}{c}\text { Bakauheni Selatan }- \\
\text { Pelabuhan }\end{array}$ & \multicolumn{2}{c}{ Kalianda-Pelabuhan } \\
\cline { 2 - 5 } & \multicolumn{1}{c}{ Luas (m2) } & Luas (m2) & Total Luas (m2) & \multicolumn{1}{c}{$\%$} \\
\hline Perkebunan & $1.843 .024,90$ & $459.171,00$ & $2.302 .195,90$ & 72,13 \\
Tanaman Pangan & $771.973,00$ & $29.866,00$ & $801.839,00$ & 25,12 \\
Permukiman & $59.383,00$ & $28.449,00$ & $87.832,00$ & 2,75 \\
\hline Jumlah & $2.674 .380,90$ & $517.486,00$ & $3.191 .866,90$ & 100,00 \\
\hline
\end{tabular}

Pembangunan Jalan Tol dari pintu Gerbang Tol Kalianda sampai pintu Tol Pelabuhan Bakauheni setelah dilakukan perhitungan diperoleh data bahwa pembangunan jalan telah mengkonversi lahan seluas 3.205.771,90 m2. Tutupan lahan yang terkonversi terdiri dari lahan perkebunan, lahan tanaman pangan, dan lahan permukiman seluas 3.191.866,90 m2. Total luas lahan yang ada 72,13 persen merupakan lahan perkebunan dan 25,12 persen merupakan lahan yang ditanami komoditi pertanian. Berdasarkan data yang tersaji diperoleh informasi bahwa pembangunan jalan tol hampir seluruhnya mengambil lahan potensial pertanian baik lahan yang dimanfaatkan untuk perkebunan maupun tanaman pangan.

\section{KESIMPULAN}

Pembangunan Jalan Tol menyebabkan adanya konversi lahan pertanian potensial yaitu area perkebunan 72,13 persen dan 25,12 persen merupakan area tanaman pangan.

\section{DAFTAR PUSTAKA}

[BPS] Badan Pusat Statistik Provinsi Lampung. (2018). Lampung Selatan dalam Angka. Bandar Lampung (ID).

BPP Kabupaten Lampung Selatan dan LPPM Unila (2017) Kajian Dampak Sosial Ekonomi Pembangunan Jalan Tol Kabupaten Lampung Selatan. Lampung.

Destianto, R. and Pigawati, B. (2014) 'Analisis Keterkaitan Perubahan Lahan Pertanian Terhadap Ketahanan Pangan Kabupaten Magelang Berbasis Model Spatio Temporal Sig', Geoplanning: Journal of Geomatics and Planning, 1(1), pp. 21-32. doi: 10.14710/geoplanning.1.1.21-32.

Harian Pilar (2017) Keberadaan Jalan Tol Merubah RTRW Lamsel. Available at: http://www.harianpilar.com/2015/10/29/keberadaan-jalan-tol-merubah-rtrw-lamsel/.

Khasanah, U., Nugraha, N. and Kokotiasa, W. (2017) 'Dampak Pembangunan Jalan Tol SoloKertosonoterhadap Hak Ekonomi Masyarakat Desa Kasreman Kecamatan Geneng Kabupaten Ngawi', Citizenship Jurnal Pancasila dan Kewarganegaraan, 5(2), p. 108. doi: 10.25273/citizenship.v5i2.1644.

Norfahmi, F. et al. (2019) 'Perubahan Penggunaan Lahan dan Sosial Ekonomi Rumahtangga Petani Terdampak Gempa Bumi, Likuifaksi, dan Tsunami di Provinsi Sulawesi Tengah', in Teknologi Pertanian, pp. 56-63. 
Pandian, M. et al. (2014) 'Land Use and Land Cover Change Detection Using Remote Sensing and Gis in Parts of', International Journal of Remote Sensing \& Geoscience (IJRSG) www.ijrsg.com, 3(September). Available at: www.ijrsg.com.

Putra, W. P. (2014) 'Pemanfaatan uang ganti rugi lahan pertanian (studi kasus pembangunan Jalan Tol Di Desa Kedunglosari, Kecamatan Tembelang, Kabupaten Jombang)', Journal Air Langga, 3(2).

Sadono Sukirno (2016) Mikroekonomi Teori Pengantar. 3rd edn. Jakarta (ID): Rajawali Pers. 